Journal of the British Association for Chinese Studies, Vol. 8 (2), July 2018

ISSN 2048-0601

(C) British Association for Chinese Studies

\title{
Playful You in the Zhuangzi and Six Dynasties Literati Writing
}

\author{
Xiaofan Amy Li \\ University of Kent
}

\begin{abstract}
This essay explores the notion of you 游 in the Zhuangzi and Six Dynasties literati writing through a comparative reading. Used interchangeably with its variant you 遊, you 游 has various uses and meanings, from the more literal "swim in water", "move in an unobstructed way", "wander", and "travel afar", to its extended meanings including "ramble in a carefree way", "travel playfully", "travel into foreign or unknown space", or "enjoy a leisurely activity". You is also, significantly, combined with other characters to form compound expressions specifying different playful activities, e.g. youxi 游戲: "play and frolic", "amuse oneself", or "game"; youwan 游玩: "play outdoors" (with an emphasis on movement); and lüyou 旅游: "travelling for leisure", or "tourism"-which have very different connotations from lüxing 旅行, "journey", or "travel (the main purpose of which is not pleasure)". In these different uses and expressions of you, in both classical and modern Chinese, what we find in common is the connotation of an unhindered, playful movement that is closely connected to its spatial context. In the context of the Zhuangzi and Six Dynasties literature, therefore, can we find articulations of you as a playful activity? If yes, in what specific ways is you playful, especially in regard to the space and context in which it occurs? Finally, what do the differences and similarities between the Zhuangzi and Six Dynasties writing say about the evolution of the notion of you within the Daoist and NeoDaoist discourse?
\end{abstract}

Keywords: you, Zhuangzi, Six Dynasties, play, Daoist, Neo-Daoist.

The Zhuangzi is a crucial early Chinese text for understanding you 游. Not only does the term itself recur constantly throughout the text, but also the idea of a carefree and playful roaming (xiaoyaoyou 逍遙游) has become the hallmark of the Zhuangzian spirit. Alan Levinovitz (2012), Victor Mair (1983), and Chris Fraser (2014) have all explicitly pointed out the centrality of a playful spirit in Zhuangzian "roaming" (you), whether it is about the sage "riding the winds", flights of imagination, or an "eudaimonistic" approach to the Dao. Brian Bruya (2010) has further related the Zhuangzi's ingeniously skilled craftsmen (often characterised by you) to Mihaly Csíkszentmihályi's idea of an effortless and pleasurable "flow experience", which characterises the spontaneous enjoyment of an extremely engaging activity that completely absorbs the agent of action into the action itself. These existing criticisms show the pertinence of exploring the playful dimension of

This essay stems from a seminar paper I presented at the Needham Research Institute, University of Cambridge, in March 2017. I thank Professor Sir Geoffrey E. R. Lloyd, Dr Yang Fu 傅揚, and Dr Kei Hiruta 蛭田圭 for their suggestions and feedback on the draft of my manuscript. I also thank the two anonymous reviewers for their constructive and detailed comments, which have helped me complete my revision. 
you in the Zhuangzi, which is what this essay purports to do, with the further aim of refining our understanding of Zhuangzian you by paying particular attention to its spatial metaphors.

As for reading the Zhuangzi comparatively with Six Dynasties literati writing, this is a meaningful comparison because although much has been said about the Zhuangzi and Six Dynasties xuanxue 玄學 (Dark Learning), especially the creative editing work of the Zhuangzi done by Guo Xiang 郭象 (c. 252-312), there is less detailed comparative discussion on the connections and specific differences between the Zhuangzi and Six Dynasties literature and aesthetics, and on how the Zhuangzian notion of you evolved in the latter. But the Zhuangzi was a constant reference point not only in Six Dynasties literati's qingtan 清談 (Clear Conversation) debates about the interpretation of old masters' texts and the Dao, but also in their poetic writing that increasingly connected you to an aesthetics of landscape on the one hand, and to literary competitions on the other. As Holzmann (1996) a shows, you appears as a key term in Six Dynasties literature that went hand-in-hand with the rise of landscape poetry and the youji 游記 (records of wandering experiences), including typical topics such as you shanshui 游山水 "wandering in mountains and waters", youyuan 游園 “wandering in parks or gardens”, you guji 游古跡 “wandering in historical sites", and youxian 游仙 "wandering to immortality". ${ }^{1}$ These Six Dynasties writings on you are seen by Paul Kroll (1996: 655) to follow the poetic traditions of “far roaming" (yuanyou 遠游) and “encountering sorrow" (lisao 離騷) that portray the Daoist "randonnée extatique" and quest to rise above worldly troubles, with the Zhuangzi as a founding inspirational source. Nevertheless, acknowledging the Zhuangzi's broad influence is not enough. We need to consider how specifically the Zhuangzi compares to Six Dynasties literature to understand both its influence and the transformation of the you motif, especially in connection to the imagination of the space of you.

In the following, I first examine some key passages about you in the Zhuangzi and discuss how they delineate spaces of play. Then I consider you in a selection of Six Dynasties literati writings that are representative in thematically connecting you to landscape appreciation and literary games. Finally, I discuss the differences and similarities between the Zhuangzi and Six Dynasties literature, aiming to shed light on the understanding of you as an activity that can be playful in different ways. Through this discussion, I argue that although the Zhuangzi provided the fundamental thematic frameworks of you for the Six Dynasties literati that preconditioned their aesthetic vision, their articulations of you contested substantially the Zhuangzian meanings of you because they formalised it as a particularly literary

\footnotetext{
${ }^{1}$ Shanshui denotes not only "mountains and waters", or what in English translation is usually rendered as "natural landscape", but also artificial landscapes like gardens, pavilions, parks, cultivated fields and woods, and the suburbs. Yuyu Zheng (2014: 143-166) even argues that it is not the actual scenery that defines shanshui poetry but the kind of poetic sensibility and attention centring on time and space that defines it. Generally, poems and rhapsodies written on the themes of "wandering in fields and forests" (you tianlin 遊田林), “wandering in parks and gardens", and "wandering in historical sites" can all be considered to be in the you shanshui genre.
} 
activity and trope, as well as added a new conceptualisation: performative and "gaming activity" as in youxi 游戲.

\section{The Zhuangzi}

The first observation to make about you in the Zhuangzi is that there is no single coherent notion of it. The text proffers, as it typically does, many different uses of the term and intriguing questions about the activity it refers to. Zhuangzian scholars (Graham, 2001: 123; Wu, 1982; Tao, 2011; Møllgaard, 2007) have observed that you is used to denote a spontaneous movement without obstruction, often in a state of pleasure and effortlessness. For instance, you is typically associated with swimming in water, as in Zhuangzi's statement that "the minnows come out and swim at ease" (shuyu chuyou congrong 儵魚出遊從容) (Zhuangzi, 2009: 17.7) in his famous debate with Hui Shi about whether the fish are happy; ${ }^{2}$ or in the story of the ingenious swimmer Confucius meets at Lüliang who swims effortlessly through a turbulent and dangerous waterfall (Zhuangzi, 2009: 19.9). You is also used in the sense of "Carefree Roaming" (Xiaoyaoyou 逍遥遊), chapter one's title, indicating rambling in a vast cosmic space like the huge Peng bird, or drifting without a particular destination and taking pleasure in a purposeless and self-fulfilling activity: "make a huge [wooden] vessel and let it float in rivers and lakes" (wei dazun er fu hu jianghu 為大樽而浮乎 江湖) (Zhuangzi, 2009: 1.3). Levinovitz and Mair have read you in these instances as a playful mood and spontaneous response to the Dao, characterising you as definitive of an "ideal free play" (Levinovitz, 2012: 481), and showing Zhuangzi as the "homo ludens" par excellence (Mair, 1983: 86). Nevertheless, I believe we need to question the apparent effortlessness of you by considering more closely where it happens. If you is a movement, then it is fundamentally a spatial activity. The space of you in the Zhuangzi, although a less examined aspect in comparison to the Daoist ethics of free wandering, is definitive in shaping the you activity itself.

To start with, an important space where you happens is in fact confined space. A good example is the story of cook Ding, who is skilled in butchering oxen and seems to dance to the rhythm of music when executing his task (Zhuangzi, 2009: 3.2). When asked how he achieves this, Ding explains (Zhuangzi, 2009: 3.2):

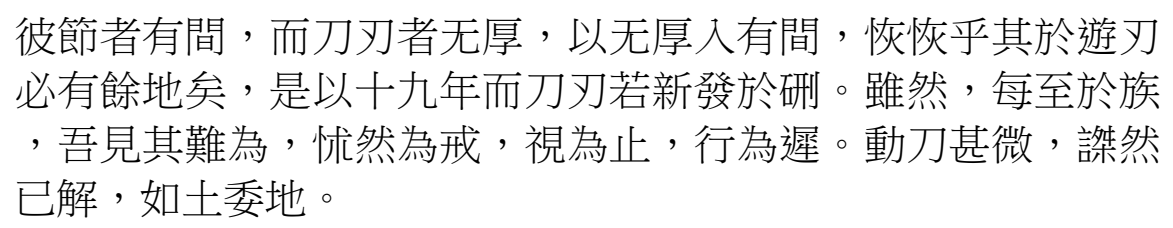

There are spaces between the ox's joints, but the knife's blade has

\footnotetext{
${ }^{2}$ All translations are my own unless otherwise indicated.
} 
no thickness. If you insert what has no thickness into such spaces, then there is vast room for the knife to wander about, indeed more than enough space to do so. This is why after nineteen years, my knife's blade is as sharp as if it had just been polished on the whetstone. Nevertheless, whenever I come to a knot of joints, I see it is difficult to cut, fearfully and vigilantly watch out for them, keep my eyes fixed and move slowly. I move the knife very subtly and in a swift crash the knot is dissolved, crumbling down like clods of earth. [My italics.]

You is used here to highlight ingenious skill: Ding's ability to avoid cleverly all the obstacles in the ox's physique and cut only where it is suitable to cut. Although Ding does this perfectly, this effortlessness comes from more than nineteen years of practice. Ding's ox-cutting, according to Carl Olson (2017: 46), manifests itself as an immersive and playful activity in the knife's "wandering" (you) movement, for it transforms a difficult task into a pleasurable act. What existing criticism has rarely remarked, however, is that the inherent risk for Ding of making a mistake is still there, implied by Ding's "fear" and "vigilance" when he comes to a knot and becomes extremely careful. Dissecting the ox successfully becomes similar to winning a game of whether one can let one's knife navigate correctly within the intricate spaces of the ox's body. If Ding's you is playful and "joyous" (Graziani, 2005: 63), then you within confinements may be understood as playing in a game-like space with strict rules. Game space, as Johan Huizinga (1949) and Roger Caillois (1958) have argued forcefully, denotes a restricted time-space within which a highly technical task is to be completed, and therefore inherently carries the risk of failure. Seen in this light, in contrast to the happy fish's carefree swimming, Ding's you is a feat here precisely because of the difficult framework in which Ding is operating: to be able to accomplish under formidable constraints something that would normally require extreme effort.

The darker side of Ding's story is the danger of losing the game. When you happens in a restricted, game-like context where something is at stake, it is a potentially dangerous activity that may not be enjoyable at all to the person who does not have supreme skill and perfect knowledge. This idea appears in chapter four "Men in Worldly Business" (Renjianshi 人間世). The chapter begins with Yan Hui coming to ask Confucius for leave to go on a diplomatic mission to persuade the Lord of Wei-known to be arrogant and cruel, "a violent man" (baoren 暴人)-to mend his ways (Zhuangzi, 2009: 4.1). Yan Hui's dangerous and difficult task carries the real threat of death if he offends the ruthless ruler, as Confucius immediately warns him. Then they discuss what is the best strategy for success in his mission. After repeatedly refuting Yan Hui's clever suggestions about how to deal with the badtempered Lord, Confucius finally says that the ultimate is to be able to you in this thorny situation (Zhuangzi, 2009: 4.1):

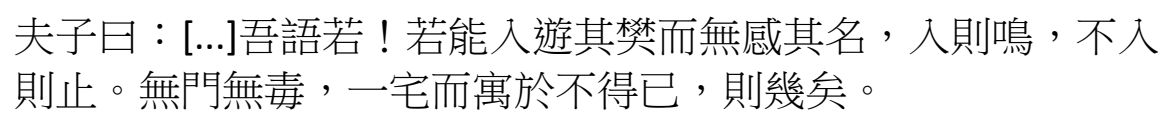


Confucius said, "[...] Let me tell you! If you can enter his [i.e. the Lord of Wei's] cage and wander there without being affected by his reputation, if your words penetrate his hearing then sing your notes, if they fall on deaf ears then desist; having no doors and no remedy, you live in the same dwelling [with him] and reside in whatever is inevitable-then you will be nearly there." ${ }^{3}$

Yan Hui is likened to a bird that enters a cage when he goes to persuade the Lord of Wei. The cage image here shows the confinement of you, and is similar to the intricacies of the ox's joints which cook Ding deals with. To emerge unscathed from his mission Yan Hui needs to respond so well to the situation that it would be as if he did not find himself in a cage at all, i.e. be completely "unaffected" (wugan 無感). You here denotes the ability to remain unendangered in dangerous and confined situations.

The case where one fails to you successfully within confinements is made explicit in the story of Zhuangzi trying to catch a bird at Diaoling, one of the very few occasions when Zhuangzi does not act wisely with his usual reassurance, and falls prey to the trap of danger (Zhuangzi, 2009: 20.8):

\section{莊周遊乎雕陵之樊, 睹一異鵲自南方來者, 翼廣七尺, 目大運 寸，感周之桑而而集於栗林。莊周曰：'此何鳥哉? 翼殷不逝, 目 大不覩。'蹇裳䠰步, 執彈而留之。睹一蟬方得美鐆而忘其身 ; 螳蜋執鷖而搏之, 見得而忘其形; 異鵲從而利之, 見利而忘 其真。莊周忧然曰：'噫! 物固相累, 二類相召也。'捐彈而反走 , 虞人逐而誶之。 \\ 莊周反入, 三月不庭。鹳且從而問之：'夫子何為頃間甚不庭乎 ?'莊周曰：'吾守形而忘身，觀於濁水而迷於清淵。[...]'}

Zhuang Zhou was wandering in the fenced park at Diaoling when he saw a strange magpie that came flying from the south. It had wings as wide as seven chi and its eyes were a good inch in diameter. It bumped against Zhou's forehead then alighted on a grove of chestnut trees. "What kind of bird is this!" exclaimed Zhuang Zhou. "Its wings are enormous but it doesn't fly well; its eyes are huge but it can't see where it is going!" He tucked up his robe, strode forward in quick and short steps, cocked his crossbow and prepared to take aim. At this moment, he spied a cicada that had found a lovely shade and had forgotten all about [the possible danger to] its body. Behind it, a praying mantis, stretching forth its

\footnotetext{
${ }^{3}$ Translation modified after Jean-François Billeter. The translation of $d u$ 毒 is particularly tricky here, "poison" does not fit here, so some other possibilities according to the Handian 漢典 are yao 藥, $d u$ 督 and zhi 治. Burton Watson's translation of $d u$ 毒 as “opening" and Graham's translation “outlet" both repeat the idea of “doors" (men 門), though $d u$ 毒 is not used in other texts in this meaning, so I have opted for "remedy".
} 
claws, prepared to snatch the cicada, and it too had forgotten about its own form because it saw only its gain. The strange magpie followed close behind, seeing the profit of catching the mantis and forgetting its true disposition. Zhuang Zhou was struck with fear at the sight and exclaimed, "Ah! Things are originally tied up with each other; different kinds incur disaster upon each other!" He threw down his crossbow and turned back running, at which moment the park keeper chased after him with curses.

Zhuang Zhou returned home and for three months was so depressed that he didn't cross the threshold to go outside the house. Lin Qie came and asked him: "Master, why are you so unhappy these days?" Zhuang Zhou said, "In clinging to my form I forgot my body. I have been gazing at muddy waters but mistook them for the clear pool. [...]" [My italics.]

The context of you here, presented in the form of a hunting pastime gone wrong, is game-like and echoes the spatial metaphor of a "bird trapped in a cage". Note the recurrence of the two terms fan 樊 and chu 忧, which appear in the passages on Yan Hui and cook Ding, emphasising the "fenced-in" space and its threatening aspect. That Zhuangzi's wandering (you) begins in such a cage-like space already carries dark overtones implying that things could go wrong. When he goes after the bird, Zhuangzi enters unawares into a predatory game one contained within another, implicating himself in a chain of parallels between the park-keeper and Zhuangzi (when he "runs" away and his you activity completely breaks down), Zhuangzi and the magpie, the magpie and the mantis, the mantis and cicada-in brief, the predator-and-prey food chain. Ironically, Zhuangzi starts by assuming himself to be the agent of the game but ends up being played by the game machine that drags him into getting entangled with things ( $w u$ 物). Zhuangzi's intention is playful but the act he gets caught up in is not pleasurable but destructive. Like the magpie forgetting its "true" body, Zhuangzi's you here is inauthentic because it is a fake semblance of the genuine you that arises from enjoyment and spontaneity like Ding's and misleads him into taking it as a genuine you activity at first. This deceptive resemblance of you is implied when Zhuangzi admits that he mistakes "muddy waters" for "the clear pool" and realises that what he believed to be a safe playground turns out to be a killing field. Inauthentic you exposes him to danger and is not at all a positive experience.

The three examples above show that the spatial context where you happens is of substantial, sometimes even definitive importance to the experience of you. ${ }^{4}$ When it is a restricted game-like space with imposed rules, it could become a trap for the person who wanders within it. If one has full grasp of the Dao then one can easily you in this threatening space, and by doing so negate its danger. If not, one may even become unaware of the risks and suffer serious consequences. Genuine you is

\footnotetext{
${ }^{4}$ There are other instances in the Zhuangzi of you in potentially dangerous spaces: e.g. in 4.7 where Zhili 支離 is exempted from military conscription, in 5.2, and 9.2.
} 
precisely the kind of spontaneous activity that is also, paradoxically, "the hardest thing to do" (Li, 2015: 102). In the Zhuangzi's words: "Only the perfect person can wander in the world and not [deliberately] shun it" (Zhuangzi, 2009: 26.8). ${ }^{5}$ You in restricted space is similar to playing a game well within constraints. The playful carefreeness usually associated with you is only the ideal case in this situation.

Nevertheless, there are also many instances in the Zhuangzi when you denotes wandering outside all confinements and any known space. Consider the story of the three friends Sanghu, Meng Zifan, and Qinzhang in chapter six. When Sanghu dies, Confucius sends Zigong to pay condolences. Zigong finds to his shock that Sanghu's two friends are playing music before the deceased and singing: "Oh! Sanghu! You have returned to what you truly are!" (Zhuangzi, 2009: 6.6). ${ }^{6}$ Zigong comes back bewildered by their complete disregard for funereal rites and tells this to Confucius, asking what kind of men Sanghu's eccentric friends are. Confucius replies (Zhuangzi, 2009: 6.6):

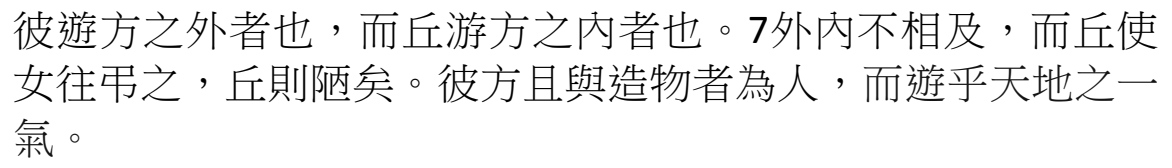
女往年之，丘則陃矣。彼方且與造物者為人，而遊乎天地之一 氣。

Those are people who wander outside the space of norms, whereas I am someone who wanders within this space. ${ }^{8}$ The outside and inside do not connect to each other, yet I sent you to pay condolences, I have been indeed vulgar! Those people are human together with the creator of things; they wander in the single breath traversing heaven and earth. [My italics.]

The contrast between two spaces: fangnei 方內 and fangwai 方外 is emphasised. The term fang, delineating a space with boundaries and cardinal directions, denotes rules, limits, and principles. Fangnei is therefore an apt description for the you within constraints of people like Confucius and Zigong, who comply with social norms and ritual codes. Fangwai is, however, beyond such limits, and denotes a space that allows one to act without "squaring" one's "emotions" with conventions (Graziani, 2006: 213), as Sanghu's two friends do by celebrating his death.

The theme of roaming the fangwai is repeated in other passages describing sagely behaviour and the Dao, pointing to an infinite space that exceeds human society and any known geographical space (Zhuangzi, 2009: 2.6):

\section{1) 至人神矣! [...] 若然者, 乘雲氣, 騎日月，而遊乎四海之外。}

\footnotetext{
${ }^{5}$ 唯至人乃能遊於世而不僻。

${ }^{6}$ 嗟來桑戶乎! 而已反其真!

${ }^{7}$ The two variants of 游/遊 here do not appear in the Guo Xiang edition of Zhuangzi (which uses 游 only). This suggests that there is no deliberate differentiation of nuance between the two variants.

${ }^{8}$ My translation of you fang zhi wai 遊方之外 takes fang 方 (“square space/realm") in the more figurative sense as "a space that is regulated and demarcated", i.e. a space of norms. This is close to Graham's (2001: 89) translation of "beyond the guidelines".
} 
The perfect person is spirit-like! [...] s/he mounts on the clouds and mists, rides the sun and the moon, and wanders beyond the four seas.

2) 篗鵲子問於長梧子曰: '吾聞諸夫子, 聖人不從事於務, 不就 利, 不違害, 不喜求, 不緣道, [...] 而遊乎塵垢之外。'

Ququezi asked Changwuzi: "I heard from the master that the sage does not work for any goal, does not pursue profit or shun harm, does not delight in quest or chase after the Dao, [...] and wanders beyond the dust and dirt."

3) 莊子曰：' [...]嘗相與游乎無何有之宮, 同合而論, 無所終窮 乎! 嘗相與無為乎! 澹而靜乎！漠而清乎！調而閒乎！翏已吾 志, 無往焉而不知其所至; 去而來而不知其所止, 吾已往來焉 而不知其所終。彷得乎馮閏, 大知入焉而不知其所窮。

Zhuangzi said: "[...] Suppose you join me in wandering in the palace of nothing-at-all, converge all the directions and discuss things, then there would be no end or exhaustion! ${ }^{9}$ Why not join me in non-action? So calm and still! Empty and pure! Harmonious and leisurely! Making myself devoid of intents, not going anywhere and not knowing where I arrive; coming and going but not knowing where it stops, I have been there and returned but do not know where it ends. Wandering irresolutely in this boundless vastness, great knowledge enters it but does not find its limits."

These spaces of "beyond the four seas", "beyond the dust and dirt", and "the palace of nothing-at-all" are all fangwai-a space where the sage wanders in perfect nonaction. This fangwai is beyond conceptualisation and no longer describes any real space with a sense of place and identity. It is a formless and undifferentiated emptiness, and you there does not carry any intentionality but is an abstraction rather than empirical experience. Because you is purposeless, it is appreciated for its intrinsic value; because it is also un-self-conscious, it is not shaped by any particular form of activity. As Jean Lévi (2010: 256) observes, Zhuangzian space is "de libre jeu et de libre choix où l'on peut s'ébaudir en toute liberté sans que l'activité de la conscience intervienne". That fangwai points towards a free you that is open and not bound by any rules is unmistakable, but it is free also in the sense of "being without": this wandering is not a choice, its experience has neither agent nor object, and its joy is impersonal (e.g. the grammatically subjectless sentences in passage three).

\footnotetext{
${ }^{9}$ My translation of tong he er lun 同合而論 is more literal and emphasises the sense of levelling all directions (undifferentiated space). Graham's translation (2001: 161) provides more information: "where you put things in their places by joining them as the same".
} 
It is important to note that in early China, as Mark Edward Lewis (2005) argues, space was organised into units that facilitated administration and hierarchical ordering, often in chequerboard pattern. The square: fang 方, thus carried the symbolic meaning of orderly and mapped territory. To travel afar (you) was conventionally seen as an unwise and risky activity because it meant not only leaving one's family and homeland but also going beyond known space into the wild where strange and threatening creatures and spirits thrived. ${ }^{10}$ Set against this background, the Zhuangzi's reversal of the usual negative connotations of you in fangwai becomes even more remarkable: when one throws oneself open to a nameless, nonhierarchical and unknown cosmos (fangwai), and wanders there in an unrestricted and impersonal state where rules do not exist or can be freely invented and changed, it is a sign of perfection and "great knowledge" rather than unwise and inauspicious behaviour. On the other hand, it is also implied that this nameless fangwai is dangerous for those who are not "perfect persons" (zhiren 至人) to wander in, and could be potentially as risky as travelling afar in the threatening spaces as described by Lewis.

Two types of you in the Zhuangzi have so far been observed: "wandering within" (younei 遊内) and “wandering outside" (youwai 遊外). Paula Varsano remarks that this division between moving in fangnei or fangwai uses space to conceptualise "two stages of being: [...] before and after attaining sagehood" (Varsano, 1996: 385). But the above passages show this spatial division reveals that the question is not only about attaining sagehood but also about you as an enjoyable and playful activity. In cases where you is without personal subjectivity as shown above, you is dissociated from any agent and points to an impersonal joy that can be characterised by the Zhuangzi's (18.1) epithet, "the ultimate joy has no joy" (zhi le wu le 至樂無樂). Besides this subjectless you in fangwai, fangnei relates in particular to the question of skilful you. The Zhuangzi includes numerous portrayals of people who are incredibly skilled at something very specific: be it butchering oxen, the Lüliang swimmer, the cicada-catching hunchback of Chu (Zhuangzi, 2009: 19.3), or carpenter Shi slicing off cleanly with a whirling hatchet the mud on his friend's nose without hurting the nose at all (Zhuangzi, 2009: 24.6). These are all feats accomplished by working within strenuous conditions and undertaken for their intrinsic pleasure. ${ }^{11}$ If fangnei is this game-like space of you that provides the framework for these people to cultivate and perfect their skill, then fangnei takes on a positive value and can be roamed as if it were fangwai.

In sum, I have argued that in the Zhuangzi, two contrasting spaces of you can be established, which set the directions of you's thematic development for later writers, namely: leisurely and spontaneous movement; playful behaviour and mood; constraints in a game-like space that can only be overcome by supreme skill; imaginative flights beyond the mundane world into infinite cosmic space; the perfect

\footnotetext{
${ }^{10}$ See Analects 4.19 on travelling.

${ }^{11}$ In Ding's case, although butchering is his profession, he has transformed the task of butchering into a pleasurable activity, which is not a job requirement. His pleasure is therefore a surplus that he enjoys as an intrinsically valuable experience.
} 
person who wanders in the world and is carefree. ${ }^{12}$ These connotations of you were fully exploited by Six Dynasties literati, who took you as a motif and activity that typically carried Zhuangzian overtones. Nevertheless, Six Dynasties literature reveals different conceptualisations of you and what constitutes fangnei and fangwai, which I now turn to examine in detail.

\section{You in Six Dynasties Literati Writing}

As a theme in writing, you gradually emerged in Six Dynasties literati writing as loosely grouped around two senses of you. One is wandering and travelling in a landscape or outside one's native land, for instance in the poetic writings by Xie Lingyun 謝靈運, Sun Chuo 孫綽, Tao Qian 陶潛, and the rhapsodies referenced by Lu Ji 陸機 in his Wenfu 文賦 and the youlan 遊覽 section in Xiao Tong's 蕭統 (501-531) Wenxuan 文選. Secondly, the meaning of "playing games" and "entertainment" as in youxi 游戲, especially in the context of literary games and competition at literati gatherings and court parties, also became prominent. These two senses of you are not mutually exclusive and their associating contexts sometimes overlapped, for instance the famous Orchid Pavilion 蘭亭 gathering in 353 (discussed later), which was both an excursion in a scenic landscape and a party where poetry composition contests were held. In the following, I consider a few representative texts spanning the broad chronological scope from 200-600 that relate to the notion of you as a playful activity -in both senses of wandering leisurely (in space) and gaming as in literary competition or tasks that require great skill to accomplish. ${ }^{13}$ What emerges from these diverse Six Dynasties writings on you is that, as I argue, you becomes established, in literary repertoire, as a distinct characteristic of literati lifestyle and aesthetic sensibility.

To begin with, we may consider the prominent Three Kingdoms political thinker Zhong Changtong's 仲長統 (180-220) Essay on Delighting the Mind (Le zhi lun 樂志 論), which sets the tone for much later Six Dynasties writing about you as representative of a leisurely life detached from officialdom. Zhong was known for his defiant and openly critical attitude, which earned him the nickname kuangsheng 狂 生, or "madman". But he eventually served as "Director of the Department of State Affairs" (shangshuling 尚書令) (Hucker, 1985: 412) for Cao Cao 曹操 (c. 155-220). His Essay is written in the subjunctive mood where he envisages his ideal life after

\footnotetext{
${ }^{12}$ This does not mean that all instances of you in the Zhuangzi fall into either of these two spaces, e.g. the Hao debate between Zhuangzi and Huizi (17.7) about the fish is quite ambiguous (the fish can you happily only in water, which is a pre-condition and some kind of constrained space; whereas for Zhuangzi and Huizi, this debate seems made possible because they are specifically located on the Hao (a spatial constraint), although Zhuangzi's argument that he can know the fish's joy implies he transgresses the epistemological fang 方 of his own subjectivity, which Huizi argues he cannot transgress). My argument here is however that fangnei/fangwai spaces can represent quite a number of exemplary instances of Zhuangzian you and can connect to later Six Dynasties articulations on the you motif.

${ }^{13}$ As discussed in more detail in the conclusion, you in Six Dynasties literature can be seen as narrowings of the meanings of you in the Zhuangzi.
} 
retirement from political office: "no need to work, dwelling in a landscape garden" where he could ramble about, meditate on the wisdom of the ancients, and "communicate with friends who shared noble interests with him" (Yan, 2015: 1201).

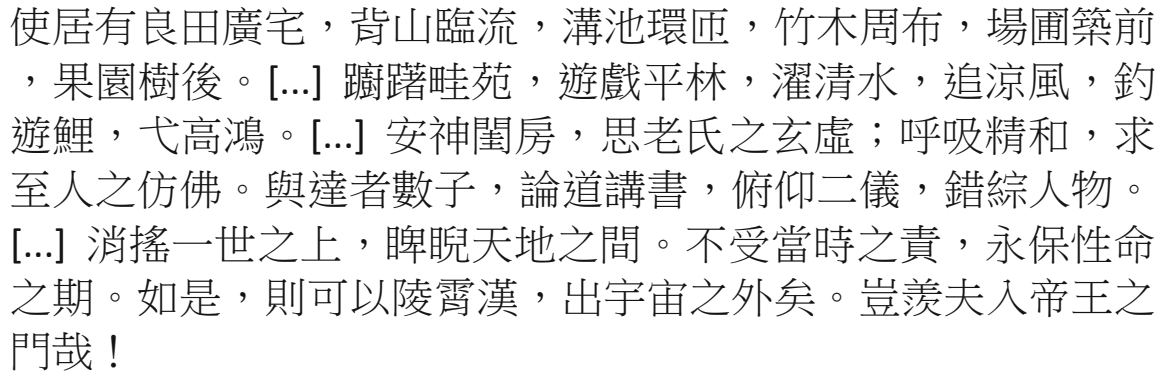

I would have as residence fertile fields and a spacious house, with mountains behind and overlooking a stream, encircled by canals and covered with bamboo and trees. There would be a vegetable patch and threshing ground in the front with a fruit orchard planted behind. [...] I would stroll about in the fields and gardens, wander and play in woods planted on flatland, dapple in clear water, chase the fresh winds, fish for the swimming carps, and shoot the wild swans that fly high. [...] In my private rooms I would still my spirit and meditate on the dark mystery and emptiness of Laozi; my breath would be refined and harmonious, so that it would be similar to the perfect person. With extremely knowledgeable people I will play go, discuss the Dao and old masters' texts, contemplate the sun and the moon, and comment on diverse people and things. Being carefree I would surpass my contemporaries, and look disdainfully at this world between heaven and earth. I would not be reprimanded by my contemporary world, and would preserve eternally my lifespan. If I could live like this, then I could ascend the clouds and skies, going beyond time and space. How could I ever desire to enter officialdom and serve any emperor or prince $!^{14}$ [My italics.]

The landscape here is cultivated to suit Zhong's taste and lifestyle, one which he can aesthetically appreciate and wander (you) in. The term youxi 遊戲 conveys the playful mood of his leisure activities; and youli 遊鯉 (swimming carp) echoes the Zhuangzian imagery of happy fish. Other references to the Zhuangzi are found in xiaoyao 消搖, (being carefree), and Zhong's self-image of ascending the clouds, which adopts the Zhuangzi's imaginative depiction of the perfect person's extraordinary capacities of "riding the wind and clouds" and merging with cosmic space, as cited above (Zhuangzi, 2009: 2.6). In the last sentence, Zhong opposes this reclusive lifestyle of leisure and self-cultivation to the space of officialdom, described metaphorically as "entering the gates of emperors and princes" (diwang zhi men 帝 王之門). The space of you is outside the mundane world (yuzhou zhi wai 宇宙之外), thus it is fangwai to political office and public life, constructed here as a restricting

\footnotetext{
${ }^{14}$ Translation modified after Holzman (1996: 72).
} 
fangnei where Zhong cannot be "carefree". It is worth noting that Zhong's fangwaia deliberately constructed space befitting his status and lifestyle as a scholar-official in retirement-is clearly very different from the Zhuangzian fangwai. Later scholars like Dong Qichang 董其昌 (1555-1636) and Qian Zhongshu 錢鍾書 (1910-1998) have criticised Zhong for insincerely depicting an extravagant life that only rich and privileged literati can afford rather than real hermitage (Qian, 1998: 86). This raises the question of whether you became a purely literary trope to express admiration for Zhuangzian carefreeness and Daoist reclusion without the real intention to experience them. Nevertheless, regardless of whether Zhong was sincere in wishing to retreat from political responsibility, his essay shows that you was already a motif that gave rise to the aesthetic appreciation of landscape and the scholar-official's aspiration to reclusion and self-cultivation.

\section{Xie Lingyun 謝靈運}

Xie Lingyun's (385-433) Rhapsody on Mountain Dwelling (Shanju fu 山居賦)-a monumental piece in the history of Chinese poetic appreciation of landscape and firmly established in the youji 游記 tradition (Swartz, 2015; Zheng, 2014)-develops much more elaborately the themes in Zhong's essay about literati reclusive lifestyle and the pleasures of wandering in landscapes. Xie was from the prominent aristocratic Xie clan of the Eastern Jin (317-420) and later served as official in the Liusong dynasty (420-479). In 423, Xie returned to his ancestral home estate in Shining 始寧 (in modern Zhejiang) "after a period in exile as the Governor of Yongjia 永嘉 between 422-423" and took a period of retreat there (Swartz, 2015: 21). The estate was inherited from his grandfather Xie Xuan 謝玄 (343-388) and it enclosed mountains, rivers, and lakes, offering an ideal residence for reclusive life. During his retreat and until 426, Xie substantially expanded and re-constructed the estate grounds. The composition of Rhapsody took place after this construction project when Xie was ill and had to spend much time in bed. Rhapsody was written in full consciousness of Zhong's essay (which Xie cites) and contains many references to the Zhuangzi. It describes Xie's excursions and physical experiences of viewing, cultivating, and wandering in the estate lands which he constructs to suit his poetic vision of shanshui (mountains and waters). In the beginning section, Xie declares his intention and mental state (Xie Lingyun ji, 1987: 318-334):

\section{謝子臥疾山頂, 覽古人遺書, 與其意合, 悠然而笑日：夫道可 重, 故物為輕 ; 理宜存, 故事斯忘。[...]合宮非經雲之館, 唒室 豈放勛之堂。邁深心於鼎湖, 送高情於汾陽。㗝文成之卻粒, 愿追松以遠游。嘉陶朱之鼓棹, 乃語種以免憂。'}

Lying sick in the high mountains, I read the texts left by the ancients. When I find myself agreeing with their ideas, I smile in 
contentment and say: "The Dao is important, therefore things are light in comparison; structural patterns should be preserved, therefore particular deeds are then forgotten". [...] Palaces were not the right residence for the Yellow Emperor; royal council chambers could not be Yao's abode. One went deep into the heart of Dinghu mountain; the other carried his noble sentiments to dwell in Fenyang. I gasp in admiration at Zhang Liang, who forfeited the world to follow Master Red Pine in roaming afar. I praise Fan Li for abandoning his position and becoming a boatman, telling Wen Zhong that it was to evade worldly troubles. ${ }^{15}$

By extolling Zhang Liang 張良 (c. 250-186 BCE) and Fan Li 范蟲 (536-448 BCE) for their renunciation of high positions of power to become carefree wanderers, Xie expresses admiration for abandoning the world and roaming afar. He also praises Yao and the Yellow Emperor for preferring residences in nature (Fenyang, Dinghu mountain) over palaces and state buildings, making an analogy to his own residence situated in mountains and woods-typically the symbolic abode of Daoist hermits. Reference to these precedents implies that Xie wishes to imitate them, and that the main purpose of his retreat into his mountain dwelling is to better experience eremitic life with its pleasures of wandering. As the poetic composition goes on to unfold the beautiful views of the estate grounds, we understand that the activity of you is crucial because Xie is depicting an ideal environment for him to ramble in.

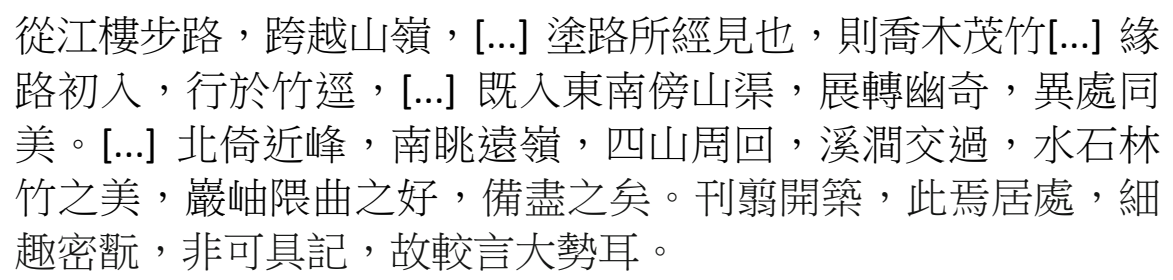

Walking on the path from the river pavilion, I cross the mountain peaks [...] I see along the way tall trees and thick bamboo groves [...] Following along the road and upon entering [the valley], I continue walking along the bamboo paths, [...] after entering from the south-eastern side, alongside the mountain canals, the path twists and changes at quiet and unexpected places, which are all different locations but equally beautiful. [...] To the north, it leans against the nearby peaks; to the south, one sees the distant mountain ranges. Mountains surround all four sides; creeks and streams crisscross each other. The beauty of waters, rocks, forests, and bamboo, and the fineness of rocks, caves, river bends and curves, are complete here. I cleared the ground and opened it up for constructions. This is where I live. It is impossible to

\footnotetext{
${ }^{15}$ Zhang Liang was an important strategist serving Emperor Gaozu 高祖 of the Western Han (Xi Han 西漢) (206 BCE-9 CE), and is known for retiring from his position to follow Master Red Pine, a legendary Daoist immortal; Wen Zhong 文種 was Fan Li's colleague in serving lord Goujian 勾踐 (c. 520-465 BCE) of Yue 越 (?-334 BCE), and was later killed by Goujian.
} 
comprehensively record each small pleasure and intimate entertainment [I obtain here], so I have merely provided a general account. $^{16}$

The landscape described here provides infinite satisfaction to Xie the wanderer who traces his roaming path through these lands as he describes their different spots and perspectives. Thus Rhapsody manifests itself as a travelling record as well as an account of his construction project and philosophical reflections. Unlike Zhong, whose description of landscape is generic and whose love for reclusive residence stems more from the desire to transcend society and avoid "reprimands" (Qian, 1998: 87), Xie expresses more delight in the beauty of the scenery and carefully observes its specific traits, establishing himself as the poetic subject situated in the experience of “blending sentiments with the scene" (qingjing jiaorong 情景交融). ${ }^{17}$

Overall, Rhapsody shows Xie in a mood of retirement and leisure, and confirms his estate as a reclusive space that, à la Zhong, defines negatively against the space of politics and administrative duties: a fangwai. You is again portrayed as the paradigmatic activity of the scholar-official who withdraws from officialdom to contemplate on life and ancient wisdom. But Xie's fangwai is not outside known space or human conceptualisation as is Zhuangzian fangwai because it is deliberately designed and full of Xie's sense of individuality and style. Xie's rambling walks through his estate-wearing wooden clogs he designed for the special purpose and in lands which he owns and controls-are not an impersonal you but a fully selfconscious playful activity where his aesthetic sensibility emerges. In other words, you in Xie's Rhapsody is an experience grounded in his subjectivity and the particularity of place, which introduces something substantially new and different from the Zhuangzi. Varsano has raised the question of whether, instead of actually travelling in landscape and relying on empirical perception, Six Dynasties poets "saw landscape 'through the lens' of received texts" (Varsano, 2013: 35), e.g. the literary repertoire on the poetics of space (the Zhuangzi, Zhong, Shi Chong, etc.) which Xie draws upon. But Xie's assertion of his subjectivity in a particular environment shows that his poetic vision stems from concrete experience, with him having full agency in shaping his space and playing in it. ${ }^{18}$ Of course, the physical activity of you goes hand-in-hand with its significance as literary motif, for the former provides the springboard for Xie's poetic expression and aesthetic contemplation, which he articulates in writing. Xie's travel record in the Rhapsody was, after all, composed after his excursions and is therefore a reconstruction of his journey and memory of the scenic views and the feelings they evoked. We may say that, to some extent, Xie constructed his estate lands to suit his taste so that they offered a delightful space for him to wander in, contemplate, then write about. The desire to create a space for you, the desire to write about you to express oneself, and the desire to you were complementary and fed upon each other.

\footnotetext{
${ }^{16}$ Modified after Swartz's translation in Swartz (2015: 24-25).

${ }^{17}$ This is not to say that disappointment with political career was completely absent from Xie's expression.

${ }^{18}$ Varsano (2013: 57) also argues that the real experience of landscape is important.
} 


\section{The Game-like Space of the Literati Party: The Orchid Pavilion Gathering}

If you in Xie's and Zhong's writings embodies the scholar-official's poetic sensibility and evokes a wandering activity in a fangwai defined by reclusive, politicallydisengaged life, then you in Six Dynasties literati parties correlates with fangnei space, especially when fang is understood in the technical sense as "rules" and "principles". You within a space regulated by rules happens in the literati party because competitive games are played between participants who share a consensus about game rules and expectations of performance. Typically, at such occasions where literati gather, poetry contests and other games such as chess, drinking, and rhetorical sparring take place. One celebrated example is the Orchid Pavilion gathering in 353, organised by the distinguished scholar-official and calligrapher Wang Xizhi 王羲之 (303-361) as a suburban excursion to the Orchid Pavilion in the mountains of Kuaiji Commandery 會稽 to perform Spring purification rites. Fortyone literati participated, all famous scholars of the time. They held a poetry composition contest to commemorate the gathering, which resulted in The Orchid Pavilion Anthology (Lanting shi 蘭亭詩), with its celebrated preface written by Wang Xizhi. Since the event was organised as a "wandering in Spring" (chunyou 春游), the poems featured the theme of you prominently. The method of competition through which the poems were produced is also notably playful: wine cups were drifted down a stream along which the poets sat, and whenever a cup stopped before a poet, he had to compose a poem (Li, 2010: 145). If he failed in the task, he would be punished by drinking three dou 斗 of wine. In addition, Wang Xizhi recorded all the poems and names of those who failed to compose under the required conditions to pass down to posterity. ${ }^{19}$ This party is therefore a game-like space with constraints, and the literati who participated were highly aware that their literary reputations were at stake.

Swartz (2012: 276) has convincingly argued that the group composition at the Orchid Pavilion party "inspires both a sense of camaraderie [...] as well as a spirit of competition, in which performers vie" with each other to display superior literary talent, wit, and philosophical understanding of the Dao. With this understanding of the poetry competition as a basis, I would like to draw particular attention to the understanding of you as a playful activity in the poems. As Wang writes in his preface:

仰觀宇宙之大，俯察品類之盛，所以遊目駎懷，足以極視聽之娛 , 信可樂也。夫人之相與, 俯仰一世, [...] 或因寄所托, 放浪形 骸之外。每覽昔人興戌之由, 若合一契; 未嘗不臨文嗟悼, 不 能喻之於懷。固知一死生為虛誕, 齊彭殤為妄作。

We look upwards at the vastness of space and time, and bend downwards to observe the richness of the myriad things. These things make our eyes wander and give free rein to our feelings, so that we can expand the pleasures of our senses of sight and sound

\footnotetext{
${ }^{19}$ See Swartz (2012: 277) for the names of those who failed to compose poems.
} 
to the limit. This is indeed great joy. In men's associations with each other that quickly span a lifetime, [...] some abandon themselves to indulge in diverse interests and pursuits, forgetting their physical bodies. Every time when I consider the causes of melancholic sentiments of men of the past, if they correspond to me, I cannot help from sighing deeply before these ancient writings, yet I cannot explain why my heart feels sad. But I know for certain that the view that life and death are one is delusional, and to make level Old Peng's lifespan to that of a child who dies prematurely is absurd (Lantingji, 1995). ${ }^{20}$

Wang's pairing of the "wandering" vision with feelings in "free rein" relates you to extreme pleasures for the senses and the mind, bringing about an aesthetic transcendence of the material body: "beyond the physical body and shape" (xinghai zhi wai 形骸之外). The last sentence directly talks back to the Zhuangzi's famous paradoxical aphorisms, "In living one is simultaneously dying, in dying one is simultaneously living" (Zhuangzi, 2009: 2.3), ${ }^{21}$ and "One may not live longer than a child who dies prematurely, yet Old Peng died young" (Zhuangzi, 2009: 2.5). ${ }^{22}$ Wang boldly dismisses the Zhuangzi's views and asserts his own knowledge: what arises from this delightful experience of roaming and communication of feelings between fellow literati is the melancholy realisation that life and its pleasures are too shortlived.

In contrast, we find a different attitude towards the ancients in the poem by Xie An 謝安 (320-385), uncle of Xie Lingyun's grandfather and a prominent statesman and poet:

相與欣佳節, 率爾同褰裳。
薄雲羅陽景, 微風翼輕航。
醇醪陶丹府, 兀若遊羲唐。
萬殊混一理, 安復覺彭薚。

Together we take joy in this delightful festival, And briskly we hike up our robes.

Thin clouds scatter the shadows cast by the sun,

Gentle winds rock the light boat.

The rich wine delights our pure hearts,

Dazed and mindless, we roam with Fu Xi and King Yao. ${ }^{23}$

Ten thousand differences blend into one principle, How can one still distinguish between longevity and early death ${ }^{24}$

\footnotetext{
${ }^{20}$ Old Peng 彭祖 is a legendary figure who supposedly lived over 800 years.

21 方生方死，方死方生。

22 莫壽乎殤子, 而彭祖為天。

${ }^{23} \mathrm{X} i$ 羲 here may be a double-entendre referring to both Fu Xi and Wang Xizhi.

${ }^{24}$ Translation modified after Swartz (2012: 288).
} 
The terms wuruo 兀若, “as if dazed, drunken, and mindless”, and chunlao 醇醪, “rich wine", imply a state of confusion and aimlessness that echoes the un-self-conscious Zhuangzian sage. Xie An's imagination of roaming with $\mathrm{Fu} \mathrm{Xi}$ and Yao expresses admiration for the ancients rather than criticism. He also re-asserts the Zhuangzi's levelling of different perspectives, including Old Peng and the dead child, pointedly contrasting with Wang's dismissal of the Zhuangzian view (Swartz, 2012: 289). Xie An's experience of you is very different from that of Wang: you is a journey of the spirit that enables him to join the illustrious ancients and harmonise with their wisdom. Instead of maintaining a distinction, Xie An aspires to a state of undifferentiation and co-existence between past and present. In this way, the difference between Xie An's and Wang's sentiments and views becomes clear. In this competitive poetic space, you becomes a common theme through which the poets express their different individual stances.

The Orchid Pavilion gathering is therefore an occasion where you-in both "wandering" and competitive "game-playing" senses of the term-is crucial. The party is not only an excursion by the participants who set out to you in landscape but also a space of competition and performance in exhibiting one's talent, expressing one's pleasure in you, and debating the understanding of ancient texts. In other words, the poets write in a playful way about their experience of you. Nevertheless, despite the apparent leisurely and delightful atmosphere of the party, it is in fact a space full of tension. Though both the intention to you playfully and the specific format of you are strongly present, what is in question is the real experience of pleasure in you. Although the poets wrote about their alleged pleasure and emotional abandonment, whether they actually found the competition pleasurable rather than stressful and embarrassing is another matter (especially for those who failed to compose good poems). Carrying explicit game rules and implicit codes of behaviour, the party is a big game of performance: not only the performance of literary composition but also the performance of you and ultimately of one's self-a self-performance that ideally matches or improves one's reputation and status. This asynchrony between the formal activity of leisurely "wandering" (chunyou 春游) and its actual phenomenological experience (dead serious rather than lightheartedly playful) is prominently manifested in the highly formalised games and competitions in Six Dynasties scholarly and aristocratic communities (of which the Orchid Pavilion party is one example), which relates back to the problems of restrictions and dangers in fangnei space which the Zhuangzi raises.

\section{Comparison and Conclusion}

We now observe a division of fangwai and fangnei for the space of you in Six Dynasties literati writing, too. For fangwai, from Zhong to the Orchid Pavilion poets and Xie Lingyun, it denotes a space that involves poetic writing about wandering (you) in landscape and a temporary retreat that suspends the scholar-official's political duties and public life. Nevertheless, the idealised reclusion in the "literary repertoire" of the scholar-official is very different from "reclusion sensu stricto" (Berkowitz, 1994: 632). After all, Zhong was certainly not "one who lived in a cave 
[...] holding the world in contempt" (Qian, 1998: 86), while Xie and the Orchid Pavilion poets were wealthy landowners who continued to engage in politics. Nevertheless, even if the Six Dynasties gentry's wanderings in landscape were an "imitation" and "watered-down version of [...] reclusive life" (Yan, 2015: 1206), it does not mean their admiration for reclusion is not genuine and their fangwai is unimportant. You in this fangwai temporarily dislodges the scholar-official from his public role, allowing him to inhabit another perspective. This is crucial for the formation of landscape aesthetics and the rise of shanshui poetry, since it brings about the experience of wandering in landscape with a clear sense of individual subjectivity and aesthetic sensibility. Besides material surroundings, landscape is also "a construct of the mind and of feeling" (Tuan, 1979: 89). You-as both physical activity and poetic motif-thus channelled concrete landscape into its representation in literature. In this way, landscape and political dis-engagement in the Six Dynasties became analogous to fangwai in the Zhuangzi. Nevertheless, there are significant differences: unlike Zhuangzian fangwai, the landscape in Six Dynasties writing is deliberately constructed and relates to particularities of time and place that define the writer's experience of you. Moreover, Six Dynasties fangwai is neither beyond the social and human realm nor beyond conceptualisation: it is in fact the negative definition of fangnei; whereas in the Zhuangzi, it is rather fangnei that is negatively defined against fangwai. Consequently, wandering in Six Dynasties literature is a fully self-conscious and often planned artistic practice within known space rather than the Zhuangzian agentless drift in cosmic emptiness. As for fangnei, it can be understood as the space of codified you in Six Dynasties intellectual sparring and literary contests. The danger of you in the story of Zhuangzi in Diaoling-i.e. being caught in a game of loss and gain-has disappeared because the scholar-official knowingly joins the game to start with. Six Dynasties literati willingly chain themselves up against each other in competing to see who can better perform under the game rules, navigate the intricacies of behavioural codes, and succeed in displaying their talent and gaining recognition. Because of this formalisation of you, even when you occurs in a space constructed as fangwai-e.g. suburban excursions or a self-imposed retreat into the mountains-you is still in a sense within fangnei because the scholar-official is acting in a way that is conventionally associated with you and considered appropriate for his lifestyle and status. In this way, although the Zhuangzi proves to be one of the biggest influences that motivated the sensibility of the wandering and gaming Six Dynasties literati, this comparison shows that the uses and understandings of you undergo a fundamental change. From the Zhuangzian realm of "nothingness" where you manifests as a playful activity of "nourishing" and enjoying life, during the Six Dynasties, you has shifted to the space of aesthetic practice that involves the game of writing, the performance of literati life, and the paradigmatic activity of poetic self-expression.

\section{References}

Berkowitz, Alan (1994), "Topos and Entelechy in the Ethos of Reclusion in China", Journal of the American Oriental Society 114(4): 632-638. 
Bruya, Brian (2010), "The Rehabilitation of Spontaneity: A New Approach in

Philosophy of Action", Philosophy East and West 60(2): 207-250.

Caillois, Roger (1958), Les Jeux et les hommes, Paris: Gallimard.

Fraser, Chris (2014), "Wandering the Way: A Eudaimonistic Approach to the Zhuangzi", Dao, 13(4): 541-565.

Graham, Angus (2001), Chuang-Tzu: The Inner Chapters, Indianapolis: Hackett.

Graziani, Romain (2005), "When Princes Awake in Kitchens: Zhuangzi's Rewriting of a

Culinary Myth", 62-74, in Roel Sterckx (ed.), Of Tripod and Palate, New York: Palgrave.

Graziani, Romain (2006), Fictions philosophiques du Tchouang-tseu, Paris: Gallimard.

Gu Shaobo (ed.) (1987), Xie Lingyun ji jiaozhu (Collected Xie Lingyun with footnotes), Zhengzhou: Zhongzhou guji chubanshe.

Holzman, D. (1996), Landscape Appreciation in Ancient and Early Medieval China, Hsin Chu, Taiwan: National Tsing Hua University.

Hucker, Charles (1985), A Dictionary of Official Titles in Imperial China, Stanford: Stanford University Press.

Huizinga, Johan (1949), Homo Ludens: A Study of the Play-Element in Culture, London: Routledge.

Kroll, Paul W. (1996), "On 'Far Roaming'", Journal of the American Oriental Society, 116(4): 653-669.

He Zao (ed.) (1995), Lantingji (Orchid Pavilion collection), vol. 2 of Gujin wenyi congshu (Ancient and modern literary series), Guangling: Guangyi.

Lévi, Jean (2010), Le Petit monde du Tchouang-tseu, Paris: Philippe Picquier.

Levinovitz, Alan (2012), "The Zhuangzi and You 遊: Defining an Ideal Without Contradiction", Dao 11: 479-496.

Lewis, Mark Edward (2005), The Construction of Space in Early China, Albany: SUNY.

Li, Wendan (2010), Chinese Writing and Calligraphy, Honolulu: University of Hawai'i Press.

Li, Xiaofan Amy (2015), Comparative Encounters between Artaud, Michaux and the Zhuangzi, Oxford: Legenda.

Mair, Victor (1983), "Chuang-Tzu and Erasmus: Kindred Wits", 85-100, in Victor Mair (ed.), Experimental Essays on Chuang-Tzu, Honolulu: University of Hawaii Press.

Møllgaard, Eske (2007), An Introduction to Daoist Thought, New York: Routledge.

Olson, Carl (2017), "Place, Play, Escape, and Identity: A Reconsideration of the Thought of Yi-fu Tuan in Light of the Work of Rāmānuja and Zhuangzi", International Communication of Chinese Culture 4(1): 35-51.

Qian, Zhongshu (1998), Limited Views: Essays on Ideas and Letters, selected and translated by Ronald Egan, Cambridge, Mass.: Harvard University Press.

Swartz, Wendy (2012), "Revisiting the Scene of the Party: A Study of the Lanting Collection", Journal of the American Oriental Society 132(2): 275-300.

Swartz, Wendy (2015), "There's No Place Like Home: Xie Lingyun's Representation of His Estate in 'Rhapsody on Dwelling in the Mountains'", Early Medieval China 21: 21-37.

Tao, Jiang (2011), "Two Notions of Freedom in Classical Chinese Thought: The Concept of Hua 化 in the Zhuangzi and the Xunzi", Dao 10: 463-486. 
Tuan, Yi-Fu (1979), "Thought and Landscape: The Eye and the Mind's Eye", 89-102, in D. W. Meinig (ed.), The Interpretation of Ordinary Landscapes, New York: Oxford University Press.

Varsano, Paula (2013), "Do You See What I See?: Visuality and the Formation of the Chinese Landscape", CLEAR, 35: 31-57.

Varsano, Paula (1996), "Getting There From Here: Locating the Subject in Early Chinese Poetics", Harvard Journal of Asiatic Studies, 56(2): 375-403.

Wu, Kuang-ming (1982), Chuang Tzu: World Philosopher at Play, New York: Crossroad Publishing.

Yan, Libo (2015), "What Landscape Meant for the Early Medieval Chinese Gentry", Asia Pacific Journal of Tourism Research 20(11): 1195-1211.

Zhang Tingyin (2008), Wei Jin xuanyanshi yanjiu (Research on Wei-Jin poetry), Beijing: Shangwu yinshuguan.

Zheng Yuyu (2014), Liuchao qingjing meixue (Environmental aesthetics in the Six Dynasties), Taipei: Liren chubanshe.

Zhuangzi (2009), Zhuangzi jinzhu jinyi (Contemporary annotation and contemporary translation of Zhuangzi) (2nd ed.), Chen Guying (ed.), Beijing: Zhonghua shuju.

Xiaofan Amy Li is Lecturer in Comparative Literature at the University of Kent. 